\title{
Urgences
}

\section{Érotique mais sans titre}

Denuis Saint-Yves

Numéro 14, août 1986

Corps et jouissances

URI : https://id.erudit.org/iderudit/025258ar

DOI : https://doi.org/10.7202/025258ar

Aller au sommaire du numéro

Éditeur(s)

Urgences

ISSN

0226-9554 (imprimé)

1927-3924 (numérique)

Découvrir la revue

Citer ce document

Saint-Yves, D. (1986). Érotique mais sans titre. Urgences, (14), 11-17.

https://doi.org/10.7202/025258ar

Ce document est protégé par la loi sur le droit d'auteur. L’utilisation des services d'Érudit (y compris la reproduction) est assujettie à sa politique d'utilisation que vous pouvez consulter en ligne.

https://apropos.erudit.org/fr/usagers/politique-dutilisation/
Cet article est diffusé et préservé par Érudit.

Érudit est un consortium interuniversitaire sans but lucratif composé de l’Université de Montréal, l'Université Laval et l'Université du Québec à Montréal. Il a pour mission la promotion et la valorisation de la recherche. https://www.erudit.org/fr/ 
Denuis Saint-Yves

ÉROTIQUE MAIS SANS TITRE 
oublions le poème*

dans ta lettre datée du III juillet

tu me disais

avoir remarqué la présence

de corps étrangers en toi*

que cela t'incommodait

même si tu croyais t'y habituer

à certains moments

faute de ne pouvoir

t'en détacher*

puisses-tu lutter*

pour ma part

j'ai aussi remarqué

la présence de ces corps étrangers

mais hors de moi*

je me sens malade

rien qu'à l'idée

qu'ils sont là

bien vivants

prêts à me prendre

à mon tour*

que puis-je y faire*

j'ai toujours eu

en horreur l'erreur.

sur la personne*

mieux que moi tu sais

que je t'aime*

baiser

Denuis 
Nadine et André m'ont écrit*

ils sont inquiets

à ton sujet

parce que tu ne sais plus

faire la cuisine*

qu'en est-il*

qu'est-ce à dire* 
merci de me rappeler

que Nadine et André sont des huissiers

du moi*

que jamais ils n'ont eu pour toi

de compréhension autre

que didactique*

plus inquiétante est la suite

de ta lettre où explicitement

tu dis n'en pouvoir plus

d'astiquer continuellement tes mécanismes

de défense*

est-ce en partie dû

aux corps étrangers*

puisses-tu casser la baraque

s'il le faut*

pour ma part

je tiens pour maudit tout corps étranger

qui ne soit pas le tien*

je ne désespère pas

d'une mi-session

dans des draps de flammes*

mieux que moi tu peux mesurer

les hypothèses de mon amour*

baiser

Denuis 
Nadine et André m'ont

à nouveau écrit* jamais je n'ai vu tant de délicatesse

dans l'asservissement d'autrui* méfie-toi* 
tu dis* et je cite* ah* beauté des flammes* mon désir je n'ai jamais su* mon désir de trotter sur la terre* impunément nue*

où en es-tu dans la baraque des nerfs* y casses-tu quelque chose* quelque assiette* jamais auparavant ton désir n'était parvenu

à se nommer* c'est fait* même à l'envers*

alors* alors* évade-toi* nomme le trottoir que tu aimes* nomme la mer que tu aimes* aime-moi*

hier* j'ai fait un rêve dans lequel j'étais pour toi devenu un corps étranger que ton organisme rejetait admirablement* je revenais sans cesse à toi mais tu me rejetais aussitôt* tu m'appelais*

baiser

Denuis 
Nadine et André m'ont envoyé une mèche de tes cheveux

une mèche noire*

je ne t'ai jamais connue que blonde*

qu'en est-il*

la lettre qui l'accompagne est indéchiffrable* 